\title{
Developmental biology teaching - the importance of a
}

\section{practical approach [version 1; peer review: 2 approved, 1 not}

\section{approved]}

John F Mulley

School of Biological Sciences, Bangor University, Bangor, Wales, LL57 2UW, UK

\author{
V1 First published: 26 May 2015, 4:126 \\ https://doi.org/10.12688/f1000research.6559.1 \\ Latest published: 26 May 2015, 4:126 \\ https://doi.org/10.12688/f1000research.6559.1
}

\section{Abstract}

The huge growth in knowledge in many areas of biological sciences over the past few decades has created a major dilemma for those of us in higher education, for not only must we adequately and efficiently convey these new facts and concepts to our students, we must also ensure that they understand and appreciate them. The field of developmental biology has witnessed such a massive growth in knowledge since the mid-1980s, driven mainly by advances in cell and molecular biology, and the development of new imaging techniques and tools. Ensuring that students fully appreciate the fourdimensional nature of embryonic development and morphogenesis is a particular issue, and one that I argue can only be properly learned via direct exposure to embryos via laboratory practicals.

\section{Keywords}

Education, teaching, developmental biology, laboratory practicals, biological sciences, active learning

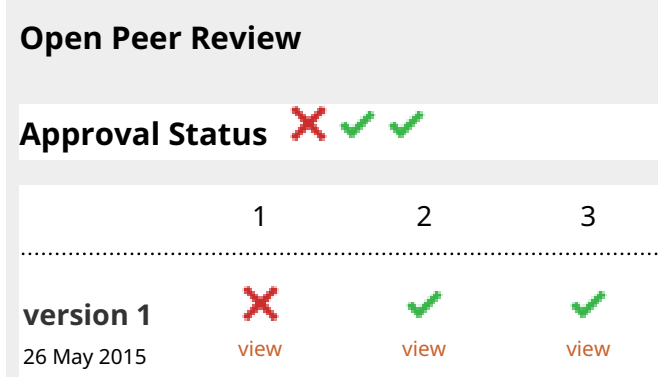

1. Graham Scott, University of Hull, Hull, UK

2. Anthony Graham, Kings College London, London, UK

3. Thomas Butts, Queen Mary University of London, London, UK Any reports and responses or comments on the article can be found at the end of the article.

Corresponding author: John F Mulley (jfmulley@gmail.com)

Competing interests: No competing interests were disclosed.

Grant information: The author(s) declared that no grants were involved in supporting this work.

Copyright: $\odot 2015$ Mulley JF. This is an open access article distributed under the terms of the Creative Commons Attribution License, which permits unrestricted use, distribution, and reproduction in any medium, provided the original work is properly cited. Data associated with the article are available under the terms of the Creative Commons Zero "No rights reserved" data waiver (CC0 1.0 Public domain dedication).

How to cite this article: Mulley JF. Developmental biology teaching - the importance of a practical approach [version 1; peer review: 2 approved, 1 not approved] F1000Research 2015, 4:126 https://doi.org/10.12688/f1000research.6559.1

First published: 26 May 2015, 4:126 https://doi.org/10.12688/f1000research.6559.1 


\section{Background}

Developmental biology is a subject with a long and rich history, and also one in which there have been tremendous and rapid advances over the past few decades. Indeed, it has recently been suggested that these advances, especially those in genetics and genomics and cell (particularly stem cell) biology, have been so great as to require a fundamental shift in developmental biology itself (St Johnstone, 2015). The British Society for Developmental Biology (BSDB) has twice in recent years considered renaming itself the "British Society of Developmental and Stem Cell Biology" (Stem Cells in Developmental Biology: a debate at the BSDB) and the flagship journal Development made a conscious effort to "...become an important player in the stem cell field" (Pourquié, 2012). Regardless of these apparent insecurities and image problems, the undoubted growth in knowledge regarding the embryonic development of an evergrowing number of species and the associated explosion of new facts and concepts, together with an extensive historical body of work, raises the issue of how best to convey these facts and concepts to undergraduate students. Whilst this issue is not necessarily unique to developmental biology (Schwartzbauer, 2003; Tunnicliffe \& Ueckert, 2007; Yeong, 2012), it has been argued that the absolute requirement for four-dimensional thinking to truly understand the patterns and process of embryonic development is one not necessarily shared with other disciplines in the biological sciences (Hardin, 2008). It has also been suggested (Wood, 2008) that the issue of teaching concepts rather than facts is more complicated in developmental biology, as much of what is taught can be considered to be both a fact and a concept. Thus it is the way that we ask students to use this knowledge that determines whether they regurgitate it as a fact, or fully appreciate it and apply it as a concept. Given these considerations, how are we to ensure that students on developmental biology courses, and, indeed, general biology, zoology or biomedical courses, not only learn, but understand the principles of embryonic development? I would argue that this is only possible through direct exposure to embryos and developmental biology techniques in laboratory-based practicals.

It is widely acknowledged that students learn best by doing and by having the opportunity to put what they have learned into practise (Kolb, 1984; Moon, 2013). In addition, the ability to design and carry out experiments is a fundamental requirement of training in the sciences (Hofstein \& Lunetta, 2004; Kirschner, 1992; Kirschner \& Meester, 1988). However, it must be borne in mind that students by their very nature do not usually practice science per se, but rather are learning to practice science (Kirschner, 1992, see also Adams, 2009 for some exceptions). Science teaching should therefore aim to familiarise students with the way that science works (Allen \& Tanner, 2003; Allen \& Tanner, 2005; Hmelo-Silver, 2004; Kendler \& Grove, 2004), whilst remembering that students lack the theoretical knowledge, sophistication and experience of a researcher. In the same way, purely discovery-based approaches can often fail to properly engage learners with the material, and guided discovery better promotes constructivist learning (Mayer, 2004). In short, behavioural activity does not equal cognitive activity and we must be careful to consider why we are getting students to perform particular tasks.

Kirschner (1992) identified three motives for implementing practicals:
1. Service to theory - the practical is used to illustrate or affirm theories taught in another setting. In this way the practical is subservient to other forms of instruction and also subservient to theory, where in fact theory and practice are interdependent.

2. Discovery as the only way to achieve meaningful learning the practical is used to provide discovery learning and process approaches in the absence of prior theoretical context. However, this relies on an assumption that reception learning cannot be meaningful.

3. As a means to distil insight or understanding from empirical work - the practical is used to provide experience to help students to understand a theory. This approach assumes that meaningful learning can take place (i.e. learners can make sense of their observations) in the absence of a robust conceptual framework.

Others propose that practical sessions are better suited to the development of specific skills (and to counter the shift towards the teaching of generic "key" skills); to learn the academic approach and to allow students to experience phenomena (Abrahams \& Millar, 2008; Collis et al., 2008). In addition, co-operative learning and group work allows students to experience multiple roles and aids in the development of collaborative skills and, together with opportunities for group discussion and personal reflection contributes towards the experiential learning cycle (Kolb, 1984; Kolb \& Kolb, 2005). Clearly, the practical approach is a powerful one, and one that can have a great impact not only on the learning process in a particular course but more widely on a student's whole skill set and entire undergraduate experience.

\section{Practical developmental biology}

Towards the end of my Postgraduate Certificate in Higher Education (PGCertHE) in 2013, I designed a 20 credit practical-based $3^{\text {rd }}$ year module ('Practical Developmental Biology') for undergraduate students in the School of Biological Sciences at Bangor University and this ran for the first time in semester 2 of the 2014/15 academic year. The rationale behind the course (reflected in its intended learning outcomes) was to provide students with an understanding of key models and techniques used to study animal development; to enable them to develop practical skills in embryology and to give them the opportunity to combine background knowledge and independent research to interpret experimental results and solve problems. Interestingly, attempts to involve the students in the design of course content via a brief pre-module survey ("What are you hoping to get out of this module?"; "Are there any particular resources that you'd like to have available, either during a module or before it starts?"; "Is there anything that you have particularly liked in other modules that I can steal for this one?"; "Is there anything you have particularly disliked in other modules that I should avoid in this one?") met with limited success (16\% response rate), although such low response rates are common, possibly as a result of survey fatigue (Porter et al., 2004; van Mol, 2014). The module comprised 21 three-hour practical sessions, ranging from fairly basic single sessions involving direct observation of chicken (Gallus gallus), zebrafish (Danio rerio) and axolotl (Ambystoma mexicanum) embryos and setting up crosses of 
Drosophila melanogaster, to more complex in situ hybridisation and immunohistochemistry experiments to detect gene expression and protein distribution which ran across multiple sessions over several weeks. In addition to developmental biology skills, students were also given the opportunity to practise key molecular biology techniques, such as DNA/RNA extraction, PCR and RT-PCR, agarose gel electrophoresis, as well as to develop and improve existing skills in general numeracy, pipetting and microscopy, among others. The module was assessed via three pieces of written work (2000-2500 word combination practical write-ups and technique reviews, each worth $25 \%$ ) and a laboratory notebook (also worth $25 \%$ ).

\section{Discussion}

Embryonic development provides the link between the genes and gene frequencies learned about in genetics modules and the animals bounding around in fields which students (especially those on Zoology courses) so desire to see on field trips. The formation of the nervous and sensory systems during development dictates behaviour, as all behaviour is ultimately dependent on the ability to sense and respond to the environment and it could also be argued that the embryo is the most important level for selection to act on to change morphology. An understanding of developmental biology is therefore important for students of the biological sciences, and vital for those on Zoology degrees. It is now generally accepted that traditional lectures are poorly suited to teaching and learning in the $21^{\text {st }}$ century, with active learning approaches (such as the "flipped classroom" (Jensen et al., 2015; Lage et al., 2000)) becoming increasingly popular. The ability to carry out practical-based laboratory classes set the sciences apart from many other disciplines, and it is therefore important that these are fully exploited in order to provide the widest possible diversity of active learning approaches.

The unique requirements of developmental biology (discussed above) make this practical approach all the more important. In 'Practical Developmental Biology', students were not only given handson experience of several key laboratory model organisms (zebrafish, chickens, fruit flies among others), they were also given the opportunity to observe embryonic development for themselves through the regular monitoring of externally-developing zebrafish embryos and the "windowing" of fertilised chicken eggs. Lectures, workshops, textbooks and even videos are no substitute for such experiences, and the obvious fascination of students confronted for the first time by a tiny, beating embryonic heart or developing limb and the eagerness with which they reach for their smartphones to record the event speaks for itself. More basically, the small class size (30) enabled students to work both individually and in pairs and the overlapping nature of the practicals enhanced time-management and selforganisation and this latter was enhanced via the keeping of a combined lab book and learning journal. The requirement to collect, stage and fix embryos of several different species enhanced microscopy and observational skills, and prompted many discussions regarding the issues with assigning distinct stages to what is essentially a continuous process. The use of antibodies to "mystery proteins" and DIG-labelled antisense riboprobes to "mystery genes" (amplified using "mystery primers" by the students themselves, from RNA they extracted and converted to cDNA) ensured that even when following protocols, students were unsure of the outcome, removing the predictable results common to many "interminable, repetitive and boring" undergraduate practical classes (Adams, 2009). Student feedback showed appreciation for "large variety of practical work"; "gaining more skills in the lab, which a general zoology degree seems to lack"; "learning new techniques" and the "...relaxed, informal atmosphere that encouraged individual work and investigation".

\section{Conclusions}

Whilst the large class sizes on many undergraduate degrees and the associated implications for physical space and resources (equipment, consumables, technical staff) can often be a barrier to practical classes, there are some subjects where the opportunity to experience size, shape, texture, sights and even smells across days or even weeks cannot be replaced. Developmental biology is one such subject and all the innovative alternatives in the world (including audio-visual resources, flipped classrooms and other active learning approaches) cannot substitute for the sheer wonder of observing embryonic development first hand.

\section{Competing interests}

No competing interests were disclosed.

\section{Grant information}

The author(s) declared that no grants were involved in supporting this work.

\section{Acknowledgements}

The author wishes to thank the various PGCertHE practitioners from Bangor and elsewhere with whom aspects of this work were discussed.
Abrahams I, Millar R: Does practical work really work? A study of the effectiveness of practical work as a teaching and learning method in schoo science. Int J Sci Educ. 2008; 30(14): 1945-1969.

Publisher Full Text

Adams DJ: Current Trends in Laboratory Class Teaching in University Bioscience Programmes. Biosci Educ. 2009; 13: 3.

Publisher Full Text

Allen D, Tanner K: Approaches to cell biology teaching: learning content in context--problem-based learning. Cell Biol Educ. 2003; 2(2): 73-81.

PubMed Abstract | Publisher Full Text | Free Full Text
Allen D, Tanner K: Infusing active learning into the large-enrollment biology class: seven strategies, from the simple to complex. Cell Biol Educ. 2005; 4(4) 262-268.

PubMed Abstract | Publisher Full Text | Free Full Text

Collis M, Gibson A, Hughes I, et al.: The Student View of 1st year Laboratory Work in Biosciences - score gamma. Biosci Educ. 2008; 11: 2. Publisher Full Text

Hardin J: The missing dimension in developmental biology education. CBE Life Sci Educ. 2008; 7(1): 13-16.

PubMed Abstract | Publisher Full Text | Free Full Text 
Hmelo-Silver CE: Problem-based learning: What and how do students learn? Educ Psychol Rev. 2004; 16(3): 235-266.

Publisher Full Text

Hofstein A, Lunetta VN: The laboratory in science education: Foundations for the twenty-first century. Sci Educ. 2004; 88(1): 28-54.

Publisher Full Text

Jensen JL, Kummer TA, d M Godoy PD: Improvements from a flipped classroom may simply be the fruits of active learning. CBE Life Sci Educ. 2015; 14(1): ar5. PubMed Abstract | Publisher Full Text | Free Full Text

Kendler BS, Grove PA: Problem-based learning in the biology curriculum. Am Biol Teach. 2004; 66: 348-354.

Reference Source

Kirschner PA: Epistemology, practical work and academic skills in science education. Science \& Education. 1992; 1(3): 273-299.

Publisher Full Text

Kirschner PA, Meester MAM: The laboratory in higher science education: Problems, premises and objectives. Higher Education. 1988; 17(1): 81-98. Publisher Full Text

Kolb DA: Experiential learning: Experience as the source of learning and development. Prentice-Hall Englewood Cliffs NJ. 1984

Reference Source

Kolb AY, Kolb DA: Learning Styles and Learning Spaces: Enhancing

Experiential Learning in Higher Education. Acad of Manag Learn Edu. 2005;

4(2): 193-212.

Publisher Full Text

Lage MJ, Platt GJ, Treglia M: Inverting the Classroom: A Gateway to Creating an

Inclusive Learning Environment. J Econ Educ. 2000; 31(1): 30-43.

Publisher Full Text

Mayer RE: Should there be a three-strikes rule against pure discovery learning?
The case for guided methods of instruction. Am Psychol. 2004; 59(1): 14-19. PubMed Abstract | Publisher Full Text

Moon JA: A handbook of reflective and experiential learning: Theory and practice. Routledge. 2013.

Reference Source

Porter SR, Whitcomb ME, Weitzer WH: Multiple surveys of students and survey fatigue. New Directions for Institutional Research Special Issue: Overcoming Survey Research Problems. 2004; 2004(121): 63-73.

Publisher Full Text

Pourquié O: A niche for stem cell research. Development. 2012; 139: 1-2. Publisher Full Text

Schwartzbauer JE: Book Review: Well Worth the Weight! Cell Biol Educ. 2003; 2(1): 16-17

Publisher Full Text | Free Full Text

St Johnston D: The renaissance of developmental biology. PLOS Biol. 2015; 13(5): e1002149.

PubMed Abstract | Publisher Full Text | Free Full Text

Tunnicliffe SD, Ueckert C: Teaching biology - the great dilemma. J Biol Educ 2007; 41(2): 51-52.

Publisher Full Text

van Mol C: Coping with survey fatigue: The impact of late reminders on web survey response. NIDI Working Paper No. 2014/15. The Hague: NIDI. 2014. Reference Source

Wood WB: Innovations in teaching undergraduate biology and why we need them. Annu Rev Cell Dev Biol. 2009; 25: 93-112.

PubMed Abstract | Publisher Full Text

Yeong FM: Moving Away from Dogmatic Knowledge Dissemination in a Cell Biology Module: Examples from Singapore. Biosci Educ. 2012; 20: 106-115. Publisher Full Text 


\section{Open Peer Review}

\section{Current Peer Review Status:}

\section{Version 1}

Reviewer Report 08 June 2015

https://doi.org/10.5256/f1000research.7043.r8756

(C) 2015 Butts T. This is an open access peer review report distributed under the terms of the Creative Commons Attribution License, which permits unrestricted use, distribution, and reproduction in any medium, provided the original work is properly cited.

\section{Thomas Butts}

School of Biological and Chemical Sciences, Queen Mary University of London, London, UK

This is a thought provoking opinion piece on the advantages, indeed the need, for practical teaching for developmental biology. In general, it is a well written piece that makes a strong case, and one that I whole-heartedly endorse. In the background section, I am a little wary of the approach to thinking about practicals whereby such activities have specific independent purposes that can be expressed in a meaningful way. Are Kirschner's three motives mutually exclusive? I would suggest not, and would avoid discussing them as such. The article describes a practical developmental biology course designed and run by the author that sounds very interesting indeed. If anything, a more thorough description of the course (including its assessment components) and its philosophical underpinnings would be useful and interesting. Also useful would be speculation on how such a course could be 'scaled up', if indeed this is envisaged. Overall, this is a interesting piece that outlines an interesting course that would benefit from more thorough elucidation.

Competing Interests: No competing interests were disclosed.

I confirm that I have read this submission and believe that I have an appropriate level of expertise to confirm that it is of an acceptable scientific standard.

Reviewer Report 01 June 2015

https://doi.org/10.5256/f1000research.7043.r8755

(C) 2015 Graham A. This is an open access peer review report distributed under the terms of the Creative Commons Attribution License, which permits unrestricted use, distribution, and reproduction in any medium, provided the original work is properly cited.

\section{Anthony Graham}


MRC Center for Developmental Neurobiology, Kings College London, London, UK

This is an interesting article that makes a solid case for teaching developmental biology via practical classes employing a range of different species and using a number of different technical approaches. It is clear that the students would gain a lot of valuable insights and depth of understanding of developmental biology by this approach. Actually seeing embryos is something that is likely to grab the imagination of most students. I would ask for a bit more information on some aspects. Could we have a clearer idea of the assessments used? What exactly were the three pieces of course work? I would also like more information on how well the course worked. Were there some areas that were more successful than others? Were some aspects of the course more difficult for the students to master than others? What aspects of the course were most engaging for the students?

Competing Interests: No competing interests were disclosed.

\section{I confirm that I have read this submission and believe that I have an appropriate level of expertise to confirm that it is of an acceptable scientific standard.}

Reviewer Report 29 May 2015

https://doi.org/10.5256/f1000research.7043.r8757

(C) 2015 Scott G. This is an open access peer review report distributed under the terms of the Creative Commons Attribution License, which permits unrestricted use, distribution, and reproduction in any medium, provided the original work is properly cited.

\section{Graham Scott}

School of Biological, Biomedical, and Environmental Sciences, University of Hull, Hull, UK

This short opinion piece extols the value of a practical approach to learning and presents an interesting question: how can we ensure that students both learn facts and concepts/principles. The question is posed in the context of developmental biology but it applies equally well to all disciplinary areas. The author develops/explains this central question well (if briefly). He then presents information about his own practice and in particular describes (very briefly) a module that he has developed and delivered (once). He presents a discussion in which elements of the module are described, and finally he concludes that his discipline is one in which practical experience is essential.

Each of these individual parts is interesting but they are not fully developed and I do not feel that they add up to a discussion of the value of a practical approach to developmental biology, nor do they currently address the question that the author poses.

An opinion piece is of course an encapsulation of the opinions of the author and in this case I agree with the opinion expressed. However for a reader to be able to evaluate these opinions and assimilate them with their own experiences it is essential that they are supported by evidence. Unfortunately I don't think the author of this paper has achieved this. The link between the introductory material and the description of practice is not a fully developed one. In fact it would 
be possible to remove the description of practice here without really changing the message that is conveyed (ideally of course the case study should enhance the message). I would recommend that the author further develops the explanation and evaluation of the design of the module in the context of both its purpose and outcomes.

Furthermore the evaluation presented here is very limited. As a reader I would like to better understand the author's aims in designing the module? the level to which these aims are achieved? how their achievement is measured/assessed? I also feel that a stronger inclusion of the student voice (through an enhanced evaluation of student perception and engagement) would strengthen the argument that this model is right in this context.

Finally it is essential that the conclusion be re-written to make better use of the evidence that the author draws directly upon in formulating his opinion.

Competing Interests: No competing interests were disclosed.

I confirm that I have read this submission and believe that I have an appropriate level of expertise to state that I do not consider it to be of an acceptable scientific standard, for reasons outlined above.

Author Response 01 Jun 2015

John Mulley, Bangor University, Bangor, UK

Thanks for the helpful review - I'll get to work on incorporating these comments and making the required changes.

Competing Interests: No competing interests were disclosed.

The benefits of publishing with F1000Research:

- Your article is published within days, with no editorial bias

- You can publish traditional articles, null/negative results, case reports, data notes and more

- The peer review process is transparent and collaborative

- Your article is indexed in PubMed after passing peer review

- Dedicated customer support at every stage

For pre-submission enquiries, contact research@f1000.com

F1000Research 